\title{
Leitura Literária: provocações para pensar o contexto escolar
}

Maria de Fátima Cruvinel ${ }^{\mathbb{1}}$

RESUMO: Mediante a compreensão de que ler é construir sentidos e de que a leitura é uma prática com forte influência na constituição da subjetividade, o presente artigo propõe-se a mobilizar algumas concepções de leitura e refletir sobre a natureza do texto literário, formulando provocações para a reflexão sobre a prática leitora e formadora da literatura na escola.

PALAVRAS-CHAVE: Concepções de leitura, Michel Foucault, Mikhail Bakhtin, prática escolar.

ABSTRACT: Bearing in mind that reading is to construct meaning and that reading is a practice that strongly influences subjectivity, this article proposes to mobilize some conceptions of reading and reflect on the nature of the literary text in order to promote a reflection on the subjectivity forming practices of reading literature in school.

KEYWORDS: Conceptions of reading, Michel Foucault, Mikhail Bakhtin, school practice.

Apesar de a leitura ter uma história, ela não é de fácil apreensão, dada a diversidade de disciplinas e áreas que dela se apropriaram (DARNTON, 1995). Há muito que os historiadores da cultura a perseguem; nas últimas décadas houve uma considerável preocupação, de campos teóricos distintos, com a leitura como prática social e suas variadas implicações. Para Certeau (2000), entretanto, a história das andanças do homem através dos textos está em grande parte por ser descoberta, e a interpretação, atividade que corre paralela à leitura e é tomada como signo de nossa época, ainda encontra-se em tenra idade. A compreensão corrente é a de que nos parece impossível a ideia de vivermos em condição de não leitores, apesar de contraditoriamente ainda ser grande o número de excluídos do universo da palavra impressa ou digital. Mais precisamente, segundo Darnton (1995), é na década de 1960 na França que se inicia o interesse contemporâneo, diferenciado do que havia até então, pelo livro. A leitura chega a ser reconhecida como uma nova e importante disciplina para diferentes campos que se ocupam de problemas relacionados à comunicação. Tal como num trabalho arqueológico, os pesquisadores percorrem a trajetória da escrita e sua recepção desde sua origem até o hipertexto, nos seus mais diversos suportes, buscando compreender, em sua incontestável efemeridade, a leitura; procurando observar como a palavra impressa afeta o homem e suas práticas culturais, no intuito de entender o livro "como uma força na história” (DARNTON, 1995, p. 110). Esse mesmo historiador adverte que já são possíveis respostas às perguntas quem, o quê, onde, e quando, mas não sobre os como e os porquês da leitura. Estas são questões que se esquivam porque não se criaram estratégias para compreender o processo interno pelo qual os leitores entendem as palavras e com elas constroem sentidos. A atividade de leitura não se trata, pois, apenas de uma habilidade.

Mas a provocação à abordagem da história da prática leitora certamente guarda relações com mais uma mudança significativa na relação do leitor com a palavra escrita:

' Doutora em Estudos Literários pela Unesp; professora de Língua Portuguesa do Cepae/Universidade Federal de Goiás. Contato: fatimacruvinel@uol.com.br. 
uma mudança nos modos de ler, na ordem da leitura. Desde a passagem da grafia à mão, pelos copistas, à escrita tipográfica, com a invenção da imprensa creditada a Gutenberg, há hoje a escrita eletrônica na tela dos microcomputadores. Trata-se de uma mudança nos suportes do texto e, consequentemente, um expressivo movimento nas práticas de leitura e no perfil do leitor, evento que tem sido considerado por especialistas como mais uma revolução da leitura. Segundo Chartier (1999, p. 26), uma primeira importante revolução, que de certa forma precedeu a revolução ocasionada pela impressão, teria sido a passagem da leitura oral para a leitura silenciosa, o que aconteceu antes de meados do século XV. Além de outras ocorridas ao longo do tempo, como a do século XVIII, que é marcada pela leitura do gênero romanesco e que inaugura uma leitura intensiva e arrebatadora, contemporaneamente, a transmissão eletrônica de textos pode ser considerada uma nova revolução. E esta supõe uma redistribuição dos papéis na economia da escrita, a concorrência entre os diferentes suportes de discurso e alteração nas relações física, intelectual e estética com o universo textual (CHARTIER, 2000, p. 22).

Como os anteriores, esse significativo movimento no campo da leitura desestabiliza ordens e modos do ler. Mesmo que os novos suportes não sejam acessíveis à totalidade dos leitores, é inquestionável sua participação na circulação das ideias na sociedade contemporânea, assim como é evidente que o hipertexto está cada vez mais presente no cotidiano. A difusão eletrônica de textos aumentou vertiginosamente, proliferam sites especializados, cujas propostas pretendem reafirmar a democratização do acesso à leitura. E certamente há muita diferença de configuração entre o leitor do papel e o leitor da tela. O leitor da era da eletrônica experimenta simultânea e instantaneamente os sentidos da visão e da audição, daí se constituir como nômade, verdadeiro vagamundo perdido, mais que o leitor da tinta e papel, no labirinto do texto. Trata-se de uma realidade cultural múltipla, em que se conjugam oralidade, escritura impressa e escritura eletrônica; uma realidade em que os textos se disponibilizam para o leitor onde ele estiver. E há, diferentemente dos suportes anteriores - por exemplo, o volumen e o codex -, uma inversão no movimento do corpo do leitor em direção aos textos:

[...] a digitalização produz uma pequena revolução copernicana: não é mais o navegador que segue as instruções de leitura e se desloca fisicamente no hipertexto, virando as páginas, transportando pesados volumes, percorrendo com seus passos a biblioteca, mas doravante é um texto móvel, caleidoscópico, que apresenta suas facetas, gira, dobra-se e desdobra-se à vontade diante do leitor. (LÉVY, 1996, p. 44)

De qualquer modo, em qualquer tempo e lugar, esteja a escrita num suporte ou noutro, a leitura é essencialmente apropriação e produção de sentidos, sobretudo se a linguagem é entendida, da perspectiva do pensamento do teórico russo Bakhtin (1995), como um fenômeno social e histórico, de natureza dialógica e heterogênea. Efetivamente, todo autor, todo escrito impõem certa ordem ou atitude de leitura, um protocolo ou esquema interpretativo; cada época estabelece modelos e códigos narrativos, aos moldes da concepção de horizonte de expectativa da estética da recepção, ou conforme uma biblioteca cultural que, como sistema de valores, orienta a escrita e a leitura. Em 
contrapartida, “cada leitor, a partir de suas próprias referências, individuais ou sociais, históricas ou existenciais, dá um sentido mais ou menos singular, mais ou menos partilhado, aos textos de que se apropria" (CHARTIER, 1996, p. 20).

Apesar de significativos, numerosos e variados estudos que abordam a leitura, e que serviram para iluminar um pouco mais as práticas sociais e culturais, essa atividade mantém-se revestida de certo mistério e continua desconcertando pesquisadores. Diferentemente do traço escrito - fixado, durável, conservador -, a leitura configura-se como escorregadia, inquieta, o paraíso perdido, de difícil compreensão. Flutuante entre a materialidade que a inscreve num dado tempo e configuração e o ato do leitor que a desprende dessa materialidade, como apreendê-la? Semelhantemente aos efeitos dos textos religiosos sobre alguns crédulos absolutos, a leitura intensiva de um texto podia absorver de tal forma o leitor, que os limites entre a ficção e a realidade se perdiam. Contudo, jovens leitores hoje podem se enternecer com as românticas cartas do apaixonado protagonista de Goethe, mas certamente não chegariam ao suicídio. Não se pode dizer que a leitura e a vida contemporâneas corram paralelas, a exemplo do romance Werther e sua influência sobre os jovens alemães da época. Mas o papel da leitura na constituição do homem, na sua relação com a cultura, a história e a sociedade, desde sua invenção até hoje, é, no entanto, inquestionável.

Malgrado a dificuldade de apreensão da leitura, parte-se da compreensão de que ler é construir sentidos e da ideia de que a palavra leitura não remete necessariamente a um conceito, mas a uma prática, cuja influência na constituição da subjetividade é inquestionável. Isso posto, o presente artigo tem o propósito de mobilizar algumas concepções de leitura e refletir sobre a natureza do texto literário, buscando, paralelamente, pensar a prática leitora e formadora da literatura na escola. Assim, este estudo aborda a atividade de leitura literária, associando-a a um público leitor específico, o jovem escolar, com o propósito de indicar possíveis implicações decorrentes da associação entre os discursos literário e pedagógico. E por entender que, na prática de sala de aula, a concepção de leitura acaba por determinar em grande parte o jogo da intrincada relação entre o leitor e o texto, interferindo no papel do professor como mediador desse encontro, uma questão fundamental é se há, para o professor, uma orientação teórica e crítica sobre a leitura. Não se trata de propor um método de interpretação, o que seria negar a natureza dúctil da palavra literária, bem como a natureza escorregadia e perecível da leitura, mas de problematizar a delicada relação literatura e escola.

Diante disso, cabe aqui afirmar a ideia-mãe da compreensão bakhtiniana de linguagem na bela concepção do filósofo russo de que a palavra terá sempre seu festival de regresso (BAKHTIN, 1997), e a ela associar outras ideias e proposições. Predestinado a interpretar, o homem sempre buscará entender os sentidos dos dizeres que o cercam. Para isso, seu olhar e ouvidos têm de se voltar para a História, cujos ecos ressoam como vozes entrelaçadas nos tantos textos a partir dos quais se fundam as práticas e os saberes do mundo. Trata-se de significativos fios de sentidos que se entrelaçam e somente se deixam entrever na transparência e por um esforço de olhar, que põe em movimento a memória discursiva. No caso específico da literatura, ela engendra "estranhos circuitos, curiosos desenhos entre o locutor e o destinatário; desdobrando-os, escondendo 
um, representando o outro, jogando indefinidamente com a primeira pessoa e com as formas possíveis da interlocução" (FOUCAULT, apud ERIBON, 1996, p. 133-4).

Para Bakhtin (1981), o texto é tecido, concebido duplamente porque urdido por redes discursivas e pela combinatória dos gêneros. O texto literário é tramado com os mais variados fios discursivos da oralidade e da escrita, provindos dos diversos focos da cultura oral e escrita, inclusive em seus desdobramentos temporais. Visto como reminiscência e antecipação dos discursos passados, cruzamento e ponto de encontros e conflitos, pluridiscursividade, deslocamento, embate, o texto literário perde a posição privilegiada que a teoria tradicional lhe concedeu, se relaciona com a história, a sociedade e a cultura, e passa a ser visto como mais um discurso, por isso determinado por coerções sociais.

Dessa imagem de tecido pode-se deduzir que o texto se configura como uma manifestação em que não se visualiza o primeiro fio tampouco o último, a não ser como efeito decorrente do trabalho da tesoura, tal como podem ser metaforizados também os movimentos de escritura e leitura. Efeito que, longe de romper o curso da tessitura, opera deslocamentos de sentidos. Na rede que compõe o tecido, a heterogeneidade de fios e meadas aponta para a dispersão, nunca para a redução de sentidos. Daí outra metáfora para o texto, a do labirinto, que Borges tão bem soube explorar na formulação da ideia de texto como um jardim de caminhos que se bifurcam.

Se o texto é tal como um jardim de caminhos que se bifurcam, como apreender-lhe os sentidos? Se não estão restritos nem no autor, nem no leitor, tampouco na materialidade do texto, não se colocando, pois, na aparência da superfície textual, como o leitor pode deles se avizinhar? E mesmo que algum sentido já tenha sido encontrado, e as letras, palavras e frases continuem as mesmas, ainda assim haveria sentido a ser buscado? Essas são interrogações que se colocam, quando nos perguntamos sobre leitura. Por outro lado, o texto não é um corpo enigmático que se apresenta ao leitor à imagem e semelhança da Esfinge em sua crueldade absoluta: Decifra-me ou devoro-te; ou uma cartola mágica de onde o leitor retira os mais diversos sentidos ou, mais improvavelmente ainda, $o$ sentido. O uso da metáfora borgeana deve pressupor que não há necessariamente um caminho que leve a um alvo desejado, assim como não há um centro.

Retomando a metáfora do escritor argentino, é pertinente considerar que a tarefa do leitor é a de adentrar o jardim e embrenhar na floresta da linguagem; ou, para falar com Eco (1994), o ofício do leitor é construir suas próprias trilhas para entrar no bosque. Recorrendo à imagem do labirinto representada pela cidade, comum ao discurso moderno, o trabalho do leitor é o de percorrer avenidas, ruas, becos, procurando construir sentidos com as palavras e cenas encontradas no trajeto. Disso, não se depreenda equivocadamente a ideia de que os sentidos de um texto, por não estarem aparentes, encontram-se ocultos, demandando, por conseguinte, um trabalho mapeado de buscas, como se o que é procurado já estivesse instalado aprioristicamente, ou seja, como se os sentidos se fizessem independentemente da experiência da leitura; ou como se fossem tesouros enterrados à espera de leitores-piratas que, despojados de qualquer sentido e história, apenas pilhassem a palavra em sua matéria bruta, sem nada dar em troca. Ora, o sentido não é algo dado previamente; é, antes, um efeito provocado pelos processos discursivos que nos envolvem a todos, leitores, com os textos que lemos, com 
nossa história e a dos textos. E a história, tal como o fio de Ariadne, não nos desampara; esse é o consolo: saber que nunca estamos sós no labirinto. Mas se não nos abandona, também não nos conduz apenas ao encontro do Minotauro e, com sua derrota, à porta que levará à liberdade. Indica-nos muito mais do que uma única saída.

Embrenhar na floresta - dispostos a ora nos perdermos entre tantas veredas e bifurcações que vão dar nas mais variadas possibilidades de sentidos, ora nos encontrarmos como sujeitos que constroem algum sentido, ainda que momentâneo - essa é a nossa sina. Isso porque texto e leitor estão indiscutivelmente ligados à história, às ideologias, às formas de produção, circulação e recepção. Daí a leitura se delinear, com traços difusos, sob a forma de palavras, gestos, nervos e paixões, pressupor movimento, consequentemente, atividade e nunca passividade de seu agente, no caso o leitor. Mas variadas possibilidades de sentidos não quer dizer quaisquer sentidos. Estes são, de certa maneira, limitados pelo contexto que, por sua vez, é ilimitado, em decorrência da heteroglossia e pluridiscursividade. Por isso é possível afirmar que há tantos sentidos quantos contextos possíveis e que há uma renovação ilimitada dos sentidos em qualquer contexto novo. Aí um paralelo com a noção de grande temporalidade, que torna o diálogo infinito e inacabável, de forma que nenhum sentido morre. A palavra, diz Bakhtin "quer ser ouvida, compreendida, respondida e quer, por sua vez, responder à resposta, e assim ad infinitum. Ela entra num diálogo em que o sentido não tem fim” (BAKHTIN, 1997, p. 357, grifos do autor).

Desse prisma, a atividade de leitura não pode ser concebida como a procura pela pedra filosofal escondida sob palavras codificadas. Ler é estabelecer com o texto, mais precisamente com as vozes nele audíveis, uma interlocução, um diálogo, aparentemente mudo, mas permeado de relações e interferências. O encontro com os sentidos não é possível sem a relação dialógica, porque a leitura é encontro e confronto, do que resta perceptível o princípio da exotopia, tanto do autor em relação ao leitor, quanto em direção inversa. Um exemplo claro de que os sentidos se constroem com base no lugar que o leitor ocupa é o movimento da interpretação de um texto nas diversas leituras que um mesmo leitor faz dele. Uma experiência de Zumthor (2000) ilustra com propriedade a dependência que os sentidos têm de suas condições de produção e recepção. Apesar de se referir a uma situação de oralidade, é possível dimensionar essa experiência para o âmbito da recepção da palavra escrita. Conta-nos Zumthor certa passagem de sua infância parisiense, quando no itinerário entre sua casa e a escola parava, com seus companheiros, para ouvir os cantores de rua. As canções, a que os meninos aderiam em coro, eram-lhes atraentes, mas assegura o teórico que o que os retinha verdadeiramente, fazendo-os se arriscarem a perder o trem, era o espetáculo. Não havia somente a canção, tudo ali a compunha, tudo ali era a canção:

Havia o homem, o camelô, sua parlapatice, porque ele vendia as canções, apregoava e passava o chapéu; as folhas-volantes em bagunça num guarda-chuva emborcado na beira da calçada. Havia o grupo, o riso das meninas, sobretudo no fim da tarde, na hora em que as vendedoras saíam de suas lojas, a rua em volta, os barulhos do mundo e, por cima, o céu de Paris que, no começo do inverso, sob as nuvens de neve, se tornava violeta. (ZUMTHOR, 2000, p. 32) 
A recepção não se restringiu, pois, às canções no que se refere à letra e à melodia; elas foram percebidas como enunciados inseridos numa situação, compreendidas dialogicamente como um enunciado que é um todo de sentido, ou seja, que envolve muito mais que a simples materialidade das canções. Não é possível afirmar que todos os textos que lemos nos deixam marcas profundas, mas certamente os que ficam inscritos em nossa memória, assim ficam em decorrência das condições que nos cercam no momento em que os lemos, em consequência do lugar que ocupamos quando da leitura. Reiterando, não lemos apenas com os olhos, mas com a carne, sangue, nervos e paixões; jamais lemos apartados de nossas lembranças, colocamo-nos inteiros nas palavras. Nossa história nos acompanha.

Daí não ser aceitável a verdade de que um texto seja depositário dos sentidos; estes não precedem o texto, tampouco se encontram nele depositados. A verdade presumida do texto não corresponde à verdade sempre adiada, sempre suspeita da leitura. Para Foucault, as margens de um livro jamais são nítidas e rigorosamente determinadas, pois "além do título, das primeiras linhas e do ponto final, além de sua configuração interna e da forma que lhe dá autonomia, ele está preso em um sistema de remissões a outros livros, outros textos, outras frases: nó em uma rede" (FOUCAULT, 1995, p. 26). Sua unidade só é possível como um feixe de relações; portanto, é variável e relativa e só se constrói mediante um campo complexo de discursos. Logo, sua leitura, como a de qualquer enunciado, se apresenta como uma produção de sentidos, uma produção que associa decodificação dos signos que compõem um texto com a percepção avaliativa do todo que o circunda, num trabalho de percepção das marcas e vestígios que apontam, no texto lido, o diálogo com outros textos.

Mas convém que essas marcas sejam vistas sempre sob suspeição, já que apresentam naturalmente derivas (como signo que são), mesmo na qualidade de simples vestígios. E pode-se dizer que é aí mesmo, no desvio, que habita o ponto nodal dos sentidos, se considerarmos com Foucault que a linguagem "não é mais do que o rumor informe fluido, sua força está na sua dissimulação" (FOUCAULT, 2000, p. 72). Nessas brechas ou vazios, no mais das vezes implícitos, subentendidos, pressupostos, a possibilidade de maior interferência do leitor no ato da leitura. Dessa perspectiva, é desautorizada a compreensão de que a leitura leva o leitor a um sentido, além de ser colocada em questão a proposta de níveis de leitura. O que há são gestos de leitura, em vez de leitura, e efeitos de sentido, em vez de sentido. Um enunciado, por sua dimensão constitutivamente heterogênea, pode ter um sentido e, ao mesmo tempo, outro, não deixando de significar o primeiro.

Isso nem sempre foi compreendido assim, apesar de bastante antiga a suspeita de que o que há na materialidade visível de um texto pode corresponder apenas parcialmente aos sentidos que esse texto pode alcançar. Com o propósito de compreender a relação entre as palavras e as coisas, Foucault (1987) toma três diferentes campos de saber em três épocas distintas - o que se entende hoje como Filologia, Economia Política e Biologia, do século XVI até o XIX, correspondendo às epistemes Renascentista, Clássica e Moderna. Em suas investigações, o filósofo constata que a semelhança prevalece na primeira episteme como conceito operatório; na segunda, a representação; na última, a historicidade.
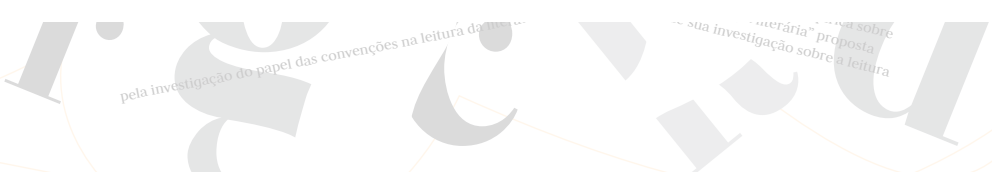
Na modernidade, a representação deixa de ser o fundamento geral de todas as ordens possíveis, de tal forma que a linguagem como que se desvanece, cedendo lugar a uma historicidade que penetra profundamente no coração das coisas, uma vez que ela se refere ao modo de ser de qualquer objeto ou realidade histórica, analisados em tempo e espaço específicos, independentemente de linearidades ou causalidades dos fatos.

Nietzsche, Freud e Marx, situados no século XIX, teriam redimensionado a relação palavra-mundo, mudando a natureza do signo e modificando a maneira pela qual ele era interpretado, e inaugurando, com isso, uma nova hermenêutica (FOUCAULT, 1997). A diferença operada na modernidade, mais notadamente por esses três estudiosos, diz respeito à forma de relacionar profundidade e exterioridade, acentuando-se a segunda; além de a interpretação ter se convertido numa tarefa infindável. Os símbolos passam a ser vistos em cadeia, numa rede inesgotável e infinita, dada sua amplitude e abertura irredutíveis.

Interpretar torna-se, então, uma atividade em perpétuo acabamento porque está sempre a remover as camadas de sentidos, como numa avalanche e, sobretudo, porque nada se oferece em estado puro a ser interpretado pela primeira vez; tudo é, já, interpretação: o signo é em si interpretação. E se o homem presta-se a essa tarefa - ou talvez seja melhor considerar que se trata de destino, ou seja, que ele está inapelavelmente condenado a interpretar sob pena de não usufruir da linguagem --, presta-se porque não cessa de haver, por baixo de tudo o que é dito, uma intrincada trama de interpretações. Como última característica dessa hermenêutica moderna tem-se a interpretação que se obriga a interpretar-se a si mesma e encontrar-se consigo mesma, indefinidamente. Como consequência, “a interpretação será sempre, sucessivamente a interpretação de 'quem?"', ou seja, o princípio da interpretação nada mais é do que o do intérprete, de forma que a palavra volte-se sempre sobre si mesma (FOUCAULT, 1997, p. 26).

Mediante essas considerações, é possível trazer novamente Bakhtin ao diálogo, retomando sua tese de inexistência de palavra original, bem como sua concepção dialógica de linguagem que sustenta a ideia de que compreender é responder a um signo por meio de signos. Com a grande diferença de que há, na base da teoria bakhtiniana, a ênfase na natureza social e ideológica da palavra. Para ele, os sentidos resultam de uma dupla corrente de manifestação: no movimento da expressão individual mas não soberana, porque nunca estamos sós quando dizemos, e nas várias camadas discursivas que revestem nossa voz. Em seus apontamentos, Bakhtin já asseverava que

\footnotetext{
O sentido não se atualiza sozinho, procede de dois sentidos que se encontram e entram em contato. Não há um "sentido em si”. O sentido existe só para outro sentido, com o qual existe conjuntamente. O sentido não existe sozinho (solitário). Por isso não pode haver um sentido primeiro ou último, pois o sentido se situa sempre entre os sentidos, elo na cadeia do sentido que é a única suscetível, em seu todo, de ser uma realidade. Na vida histórica, essa cadeia cresce infinitamente; é por essa razão que cada um dos seus elos se renova sempre; a bem dizer, renasce outra vez. (BAKHTIN, 1997, p. 386)
}

Sabemos que tanto as considerações de Bakhtin quanto as de Foucault referem-se aos discursos em geral, incluindo-se, evidentemente, o discurso poético. A palavra é 
sempre plural e inacabada, e essa peculiaridade não poderia deixar de se evidenciar na literatura, mesmo que este seja um discurso que chega ao interlocutor com uma autoria assinalada. Como vimos, a figura do autor coloca-se como uma posição ou função, e de maneira semelhante colocam-se os leitores que, no ato da leitura, encontram-se igualmente situados social e historicamente. Por isso é possível pensar em uma posição-leitora ou efeito-leitor.

Assim, a produção de sentidos resulta, também no texto literário, do encontro desses interlocutores, cada qual com suas palavras carregadas de sentidos outros, nunca acabados. Uma curiosa imagem para ilustrar essa relação é a sugerida por Calvino: "O que conta para nós na obra literária é a possibilidade de continuar a desfolhá-la como uma alcachofra infinita, descobrindo dimensões de leitura sempre novas" (CALVINO, 1997, p. 205). Nesse sentido, é necessário ter clareza de que conceber a leitura como movimento infinito e plural é considerar que há leituras possíveis. Entendo que a obra se afigura como esse vegetal pela sua constituição em camadas que se recobrem reiteradamente, mas a possibilidade inumerável de sentidos não se deve apenas à obra-alcachofra, deve-se, igualmente, às diversas posições que o leitor-degustador pode ocupar, bem como ao feixe de relações que pode construir. Relações que são construídas mediante a cena da leitura e possibilitadas pela memória discursiva cultivada em imagens, tal como as lembranças de Zumthor.

Longe de se restringir a um conceito, a leitura é prática que põe em movimento a memória. No caso específico do texto literário, há quem veja literatura e memória como empresas iguais. Se entendemos a linguagem como ecos de vozes já ouvidas, uma manifestação que se constrói com o jogo da diferença e da repetição, a literatura, como todo discurso, não se faz senão de retomada do já-dito e, nessa retomada, a inclusão de um dizer novo. Assim, não é só o gênero autobiográfico, hoje bastante em moda até, que busca o passado. O escritor Moacyr Scliar sobre isso pondera:

\footnotetext{
O tema da busca da memória não se esgota só naquilo que está na consciência, naquilo que nós lembramos; não se esgota só na evocação de episódios [...]. Há uma memória mais profunda, que está no nosso inconsciente. Porque nós fazemos literatura com a nossa cabeça, usando ideias; fazemos literatura com nosso coração, usando emoções, mas precisamos também fazer literatura com as nossas vísceras. (SCLIAR, 1999, p. 146)
}

Aqui temos a voz do autor, mas e a do leitor, a incógnita peça sem a qual não se justifica a escrita? Não teria essa voz também profunda relação com a memória, quando, na atividade leitora, responde com suas lembranças ao apelo do discurso lido? Seja por casualidade, diante da familiaridade das palavras lidas, ou perplexidade, diante da extravagância do que lhe é desconhecido, é a memória discursiva que é acionada para a construção de sentidos².

E trata-se de memória coletiva somada à memória individual, tanto do autor, que também é um leitor, quanto do receptor do texto. Reiterando: somadas, mas não necessariamente em harmonia, podendo, pois, haver conflito nesse diálogo; tensão que, aliás, é constitutiva dos sentidos. Na esteira de Bakhtin, Brait afirma que o diálogo, na forma de

Aspecto que abordei no artigo "Leitura: sentidos trilhados no movimento" (CRUVINEL, 2004). 
estrutura enunciativa e forma dialógica constitutiva da existência das atividades de linguagem, "atravessa o campo de visão e desdobra as possibilidades do ver, incluindo incessantemente a história e a memória na cena de produção de sentidos e de seus efeitos" (BRAIT, 2001, p. 34). No filme "Náufrago" (2000), do diretor Zemeckis, a relação que se cria entre o protagonista solitário e a bola que encontra nos destroços do avião é um bom exemplo do diálogo, ainda que imaginário, como um requisito para a criação. Apenas quando cria um interlocutor, "Wilson", representado por um rosto que ele próprio desenha na bola com o sangue de sua mão machucada; quando se sente provocado por esse interlocutor, na cena em que desesperadamente tenta produzir fogo, o náufrago consegue entabular um diálogo imaginário e a partir daí suportar a solidão da ilha e idealizar alternativas para sua fuga, ou, como diz o próprio protagonista, "encontrar razões para respirar".

Por isso mesmo a leitura é entendida como interpretação infinita, mas não é possível desconsiderar os diversos mecanismos que subjugam os sentidos dos textos. No caso da prática leitora escolar, a própria circunscrição da leitura literária nesse ambiente apresenta-se como uma forma de controle. Contudo, o discurso não tem o controle total dos sentidos, porque, conforme Bernstein (1996), todo texto traz consigo possibilidades de significação que não se submetem a controles, assim como todo texto pedagogizado carrega consigo a possibilidade de questionar e de alterar a gramática na qual se encontra inserido.

Mas ocorre que o discurso literário tem a peculiaridade de escapar aos controles por não ter obrigação de explicar, dar respostas, mas, ao contrário, lançar perguntas e deixá-las no ar; além disso, a relação com o mundo referenciado na literatura passa antes pelo imaginário. Como representação verbal de discursos que é, como palavra que, no movimento do trabalho simbólico, dá-se a ler e, somente então, faz manifestar o homem, sempre em relação com o outro e sua história, o texto literário constitui-se em um objeto instável, permeado de pontos de deriva, oferecendo, sempre, espaços de interpretação ao leitor, espaços em que o imaginário coloca-se em grande vantagem. Se esse é um movimento constante, é porque há uma recusa a qualquer interpretação que se dê por acabada, de forma que o discurso literário carrega como marca a insubordinação. Se a pedagogização de um texto literário resulta, essencialmente, de um efeito de leitura, esse efeito pode ser provocado ou não, mas não garantido, o que é possível por se tratar desse gênero em particular.

Em uma sala de aula, ambiente vivo e ansioso pela instauração da novidade, a leitura literária pode se colocar como provocação justamente da percepção da polifonia, apontando a possibilidade de diferentes gestos de leitura. Mais que qualquer outra, a leitura literária pode ser considerada paradigma da interpretação como diálogo, como colóquio infinito cuja tessitura se faz como um tapete é feito de vários fios, matizes e pontos que se repetem para compor o todo. "Uma história é feita de muitas histórias", assevera Clarice Lispector (1989, p. 12). Muitas histórias que se repetem, mas trata-se de uma repetição que se abre ao infinito, porque ler é, mesmo na repetição, provocar rupturas, deslocar regras, trilhar desvãos, enfim, produzir a diferença. Além do mais, tal como o autor e o professor, também o leitor não tem poder de controlar os efeitos de sentido de sua leitura, seu imaginário não cessa de trabalhar. 
É momento de novamente afirmar: a palavra terá sempre seu festival de regresso. Com a palavra bakhtiniana ecoando em Foucault, reitera-se: "o novo não está no que é dito, mas no acontecimento de sua volta” (FOUCAULT, 1999, p. 26). Aqui o filósofo francês está tratando do princípio do comentário, cujo papel relevante é o de dizer sentidos que se mantinham articulados silenciosamente no texto primeiro, comentado. E esse papel consiste em certo paradoxo: "dizer pela primeira vez aquilo que, entretanto, já havia sido dito e repetir incansavelmente aquilo que, no entanto, não havia jamais sido dito". Bakhtin (1997) adverte que um texto, diferentemente da língua como sistema de recursos, nunca pode ser traduzido até o fim, já que não existe um texto dos textos, potencial e único. Não existe um texto-pai, digamos assim, que exerça completa ascendência sobre outros textos; o que pode haver são alguns fundadores de discursividade.

Da concepção de texto como um objeto inacabado ou, como um objeto que se encontra em permanente acabamento, para a ideia de infinitude da compreensão, incompletude da leitura, chega-se à conclusão de que os sentidos são produzidos na urdidura do discurso, tanto na cena da criação, quanto na cena da leitura, ou seja, no movimento incessante dos interlocutores. O poeta e ensaísta inglês Eliot (1989), tratando da relação do escritor com a tradição, pondera que é comum a crítica descobrir que aquilo de melhor da obra de um poeta, assim como as passagens que marcam o seu talento individual, pode estar justamente no que sua obra tem de retomada dos poetas da tradição. O novo, a diferença, que tanto a crítica busca exaltar na obra de um escritor, podem estar manifestos precisamente no diálogo entabulado com a tradição, cujo sentido histórico pressupõe a percepção da caducidade do passado e ao mesmo tempo a sua presença. Isto porque, continua Eliot, "Nenhum poeta, nenhum artista tem sua significação completa sozinho". É, pois, na aparente mesmice que emerge a diferença. A esse pensamento também se filia Borges. Só pelo conto "Pierre Menard, autor do Quixote" isso se comprovaria, mas também pelo seu depoimento - no prólogo ao livro O outro, o mesmo - segundo o qual muito mais que as escolas, educou-o a biblioteca paterna. Além disso, observe-se a seguinte consideração:

As línguas dos homens são tradições que carregam algo de fatal. Os experimentos individuais são, de fato, mínimos, salvo quando o inovador se resigna a lavrar uma espécime de museu, um jogo destinado à discussão dos historiadores da literatura ou ao mero escândalo. (BORGES, 2000, p. 258)

A leitura é, pois, como um diálogo infinito, no qual se escutam as palavras, por cujas frestas se percebem vestígios da memória discursiva dos sujeitos interlocutores envolvidos no processo. Ao acercar-se de um texto, o que ocorre ao leitor é a ação de escutar as palavras que dão forma à sua materialidade e ouvir a linguagem que o constitui, o que lhe permitirá perceber os sentidos discursivos e interdiscursivos que se deixam entrever em forma de diálogo com a memória e a história. E a linguagem, fazendo ouvir ecos do já-dito, como quer Bakhtin, ou como o burburinho do já pronunciado, como quer Foucault, é o que mais se faz ressoar no texto literário. Diálogo explicitado na eterna repetição e recriação das palavras, frases, textos, cenas, meias-histórias, histórias-inteiras. 
Posto isso, chega-se à comprovação de que a leitura pode ser delineada como uma "tensão nunca resolvida entre o dito e o ainda não-dito e como uma operação que tem, entre seus componentes, a ânsia de desdizer o dito para abrir no seu interior uma possibilidade de novidade" (LARROSA, 2000, p. 17). Trata-se de compreender a leitura como uma ação que faz o texto explodir e se dispersar - operação que exige sobretudo maleabilidade do leitor, especialmente se se trata de enunciado pertencente ao gênero discursivo literário. Pode-se afirmar que a leitura desse gênero, por natureza polissêmico, não cessa de sucumbir às fendas do discurso e, nesse deslizamento constante, acumula-se na forma de memória cultural, confirmando a compreensão de literatura como a "porção mais dúctil, o limite mais extremo do discurso, o espaço onde ele se expõe por inteiro, visando reproduzir-se, mas expondo-se igualmente à infiltração corrosiva da dúvida e da perplexidade" (SEVCENKO, 1999, p. 20).

Isso porque a literatura constrói-se sobre dois pilares, o imaginário e o fictício, cujos fundamentos não estão definitivamente elucidados, ou talvez fosse melhor admitir que não sejam passíveis de apreensão. A literatura não se limita a contar algo, ela é única e ao mesmo tempo desdobrada; ela é uma "fábula que, todavia, é dita em uma linguagem de ausência, assassinato, duplicação, simulacro” (FOUCAULT, 2000, p. 141). Talvez seja possível pensar que o "impulso metafórico interno da discursividade", de que fala Pêcheux (1997), esteja inapelavelmente presente na literatura, mais que em qualquer outro tipo de discurso.

Em qualquer gênero discursivo, mas principalmente no literário, tem-se a escrita como trabalho de tesoura e cola, como colagem, citação e comentário, para trazer aqui a imagem de Compagnon (1996) e associá-la à ideia de labirinto, em que nada se cria, tudo se repete no jogo da ausência-presença, morte-vida e, nesse movimento, já a diferença. Diferença do autor à qual se junta a diferença do leitor, cada um na sua singularidade constituída mediante sua maneira particular de selecionar e organizar o já-ouvido e já-lido, para responder dialogicamente ao novo texto que toma para leitura e, com isso, ressignificar. Reiterando, a escrita literária se desenha como uma rede de citações. A linguagem é seu ponto de partida e seu ponto de chegada, cabendo ao leitor deixar-se apanhar nessa rede, não sem também tramar seus pontos e amarrar alguns nós. E nesse movimento, em que também enuncia, se a leitura é entendida como atitude responsiva ativa, cabe-lhe também ocupar uma posição e colocar-se como sujeito da leitura.

Em literatura, trata-se da palavra se oferecendo ao leitor, reafirmando sua dúctil composição discursiva, passível de se reduzir a fios, estirar, distender, sem se romper; em sua natureza flexível, elástica, e ao mesmo tempo infinita e inacabada à espera de uma contrapalavra do leitor, que a fará deslizar e ressignificar mediante a posição que assume como sujeito-leitor. Longe de prescrever saberes, a literatura os põe em movimento, numa girândola sem fim, lançando não mais que provocações. Daí a leitura literária ser sempre provisória, invisível, cambiante, sempre suceder nas fronteiras, e com ela podermos ouvir os rumores das palavras, o murmúrio eterno dos textos, burburinho do festival dos sentidos. Mesmo porque a literatura, como a vida, nos coloca questão após questão, num interrogar infindo, como se estivéssemos, a cada passo, diante do breu da noite. E esta seria sua principal função, especialmente se pensarmos no con- 
texto escolar, espaço que pode ser privilegiado para a prática leitora do texto literário: provocar o aluno-leitor, apresentando-lhe questões e não necessariamente respostas.

\section{Referências}

BAKHTIN, Mikhail. Problemas da poética de Dostoiévski. Rio de Janeiro: Forense-Universitária, 1981.

Estética da criação verbal. São Paulo: Martins Fontes, 1997.

(VOLOCHINOV, V. N.). Marxismo e filosofia da linguagem: problemas fundamentais do método sociológico na ciência da linguagem. São Paulo: Hucitec, 1995.

BERNSTEIN, Basil. A estruturação do discurso pedagógico: classe, códigos e controle. Petrópolis: Vozes, 1996.

BORGES, Jorge Luis. Prólogo (O outro, o mesmo). Obras completas II. São Paulo: Globo, 2000. BRAIT, Beth. O discurso sob o olhar de Bakhtin. In: GREGOLIN, M. V.; BARONAS, R. L. (Org.) Análise do Discurso: as materialidades do sentido. São Carlos: Claraluz, 2001.

CALVINO, Ítalo. Por que ler os clássicos. São Paulo: Companhia da Letras, 1997.

CERTEAU, Michel de. A invenção do cotidiano: artes do fazer. Petrópolis: Vozes, 2000.

CHARTIER, Roger. Prefácio. In: (org.). Práticas da leitura. São Paulo: Estação Liberdade, 1996.

As revoluções da leitura no ocidente. In: ABREU, M. (org.). Leitura, história e história da leitura. Campinas: Mercado de Letras: Associação de Leitura do Brasil; São Paulo: FAPESP, 1999, p. 19-31.

. A morte do leitor? In: BARZOTTO, V. H.; RIOLFI, C. R. (Org.). Nexos: Estudos em Comunicação e Educação. São Paulo: Editora Anhembi Morumbi, ano 4, n. 6, 2000.

COMPAGNON, Antoine. O trabalho de citação. Belo Horizonte: UFMG, 1996.

CRUVINEL, Maria de Fátima. Leitura: sentidos trilhados no movimento. LINGUAGEM Estudos e Pesquisas, Catalão, vol. 4-5 - 2004.

DARNTON, Robert. O beijo de Lamourette: mídia, cultura e revolução. São Paulo: Companhia das Letras, 1995.

ECO, Umberto. Seis passeios pelo bosque da ficção. São Paulo: Companhia das Letras, 1994. ELIOT, Thomas Stearns. Tradição e talento individual. In: Ensaios. São Paulo: Art, 1989.

ERIBON, Didier. O jogo da literatura (Foucault e Barthes). In: Michel Foucault e seus contemporâneos. Rio de Janeiro: Jorge Zahar, 1996.

FOUCAULT, Michel. As palavras e as coisas: uma arqueologia das ciências humanas. São Paulo: Martins Fontes, 1987.

- A arqueologia do saber. Rio de janeiro: Forense- Universitária, 1995.

Nietzsche, Freud e Marx. Nietzsche, Freud e Marx/ Theatrum Philosoficum. São Paulo: Princípio, 1997. . A ordem do discurso. São Paulo: Loyola, 1999.

. Linguagem e literatura. In: MACHADO, R. Foucault, a filosofia e a literatura. Rio de Janeiro: Jorge Zahar, 2000.

LARROSA, Jorge. Pedagogia profana: danças, piruetas e mascaradas. Belo Horizonte: $\mathrm{Au}^{-}$ têntica, 2000. 
LÉVY, Pierre. O que é o virtual? São Paulo: Ed. 34, 1996.

LISPECTOR, Clarice. A legião estrangeira. São Paulo: Ática, 1989.

PÊCHEUX, Michel. Semântica e discurso: uma crítica à afirmação do óbvio. Campinas: UNICAMP, 1997.

SCLIAR, Moacir. Literatura e memória. In: HILGERT, J. G. et al (Org.). Formando uma sociedade leitora. Passo Fundo: EDIUPF, 1999.

SEVCENKO, Nikolau. Literatura como missão: tensões sociais e criação cultural na Primeira República. São Paulo: Brasiliense, 1999.

ZUMTHOR, Paul. Performance: recepção e leitura. São Paulo: EDUC, 2000.

REFERÊNCIA ELETRÔNICA: CRUVINEL, Maria de Fátima. Leitura literária: provocações para pensar o contexto escolar. Revista Criação \& Crítica, n. 9, p. 25-37, nov. 2012. Disponível em: <http://www.revistas. usp.br/criacaoecritica>. Acesso em dd mmm aaaa. 